\title{
Arturo Torres-Rioseco
}

\section{Agonia del tiempo}

STABA cantando al amor cuando habló el pregonero: "piñas, melones, naranjas". . ¿Será muy tarde para loar tu boca, tu boca de siempre fiesta, tu presurosa boca que podria beberse todos los rios? Me hablan los hijos, Y me hablarán los nietos, $y$ las obligaciones, Y las instigaciones, $y$ las instituciones: deberias obtener un ascenso, deberias comprarte un diamante, bañarte en aguas minerales, consultar a los médicos"... Me voy poniendo viejo... 
Yo no sé si te canto

o estoy haciendo alarde de cantarte, hago el elogio de la rosa, me duele un poco el higado.

Vienen de afuera admoniciones, y gestos flacos y sermones.

y notas tontas de notarios, iha pagado Ud. los impuestos? Yo estoy debajo de una ola, tú estás conmigo entre las algas, no tengo cera en los oidos y oigo tu canto.

Seria triste dejarte, abandonarte a los tritones, iy si no pudiera poseerte y prefiriera un juego de ajedrez? Me estoy poniendo viejo...

Mis zapatos gastados dientes de tedio en las mañanas, mi chaqueta se queda en su garfio, mi camisa bosteza, mi corbata se arruga como monja. Ayer pisé unos lirios, destripé un ruiseñor, y me quedé sin culpa indiferente, en el alba sali con sobretodo y con paraguas. Cuando estaba cantando 
se acercó el pregonero,

al correr la naranja por mis dedos

un recuerdo me atrajo

hacia tu primavera detenida.

¿Será muy tarde? ¿Será ya muy tarde

para beber champaña entre tus labios?

¿para tocar tu pelo de ceniza?

ipara cortar la rosa de tu sweater?

Hay tantas cosas, cosas,

tantos curas oscuros,

tantos preliminares que cumplir,

tantos vaivenes de aire,

tantas invitaciones $Y$ repulsas,

será bueno comprar gafas oscuras,

procurar algún premio,

comprar un coche nuevo,

olvidarse del aire $y$ de la abeja.

Ya nunca más el canto para ti,

el canto tuyo de tu voz salido,

me voy poniendo viejo. 